\title{
Management of Root Rot, Damping-off and Wilt diseases of Verbascum (Verbascum thapsus L.) using Nanometal Particles and Fungicides.
}

\section{Abdel-Wahed, G.A.}

Ornamental, Medicinal \& Aromatic Plants Dis. Res. Dept., Plant Pathology Research Institute, ARC, Giza, Egypt.

\begin{abstract}
urvey of verbascum plants exhibited typical symptoms of root rot and $\checkmark$ wilt diseases was carried out from different localities belong to BeniSuef governorate. Root rot and /or wilt fungal diseases were detected in Beni-Suef governorate during seasons 20015/2016 and 2016/2017. Mean percentages of infection were 28.3, 38.3 and 17.9 in Beba, Ehnasea and Somosta counties, respectively. Isolation trials from diseased plants resulted in fungal species identified as Rhizoctonia solani, Fusarium solani, Fusarium oxysporum, Macrophomina phaseolina and Pythium debaryanum. The most frequent fungal species were Rhizoctonia solani and $F$. solani. In contrast, $M$. phaseolina showed the lowest frequency. Pathogenicity tests carried out under greenhouse conditions proved that all the isolated fungi cause damping-off, root rot and /or wilt to verbascum plants. F. solani and $R$. solani were the most virulent fungi with the highest percentages of root rot and /or wilt. While, M. phaseolina showed the lowest in this respect. Zinc, (ZnO-NPs) and Copper, (CuO-NPs) nanoparticles, and fungicides (Topsin M, Score and Tango) were used to control the causal pathogens. Copper, CuO-NPs was the most effective treatment followed by $\mathrm{ZnO}-\mathrm{NPs}$ in inhibiting the growth of the tested fungi. Under greenhouse conditions, it was found that the fungal infection was reduced as a result of these treatments and the verbascum growth parameters were improved. Copper, $\mathrm{CuO}-\mathrm{NPs}$ proved to be the highest effective treatment against tested fungi. In the applied field experiments, all treatments induced a highly significant protection.
\end{abstract}

Keywords: Verbascum, Nanometal Particles, root rot, wilt, fungicides.

Verbascum (Verbascum thapsus L.), Family Scrophulariaceae is biennial plants known as mullien. The origin of these plants is Iraq, Iran and Afghanistan (Hamed and Mohamed, 2010). It is cultivated in small scattered areas in Egypt, especially in BeniSuef, Fayoum and Menia governorates.

Recently, this crop is cultivated in small areas and is considered a promising plant recommended to cultivate as a non-traditional plant. It is considered an export plant of the first degree and used in folk medicinal treatment for the respiratory system, such as cough treatment and chard for sputum, bronchitis, treatment of ear diseases, wounds, hemorrhoids, anti-contractions and cosmetics. Chemical components of flowers of these 
plants contain gelatin, flavonoids, triglycerides, aromatic oils, tanning materials and resins. (Hanafi and Abdel wahab, 2013). Verbascum grow as ornamental plants, used in medicinal uses, is attaked by serious diseases such as Powdery mildew, root rot and wilt (Garibaldi and Berlti 2009). At present, numbers of synthetic fungicides have been found to cause harmfull effects to humans and the environment. For this reason, many of these fungicides have been banned. It is difficult to control fungal growth because fungi have developed resistance to many conventional fungicides such as benzimidazoles and dicarboximides (Elad et al., 1992) Moreover, these traditional fungicides are becoming ineffective due to the development of new physiological races of the pathogens (Ocamb et al., 2007). Consequently, it is important to explore novel antifungal agents, which may replace the current control strategies.

In recent years, materials in nanoparticles (NPs) have received increasing attention due to their unique physical and chemical properties, which differ significantly from their conventional counterparts (Stoimenov et al., 2002). Recent studies have demonstrated antimicrobial efficacy of various NPs materials, including silver (Kim et al., 2008; Kumar et al., 2008), copper (Cioffi et al., 2005), magnesium, gold (Gu et al., 2003) and zinc oxide (Liu et al., 2009). Highly ionic nanoparticles metal oxides such as $\mathrm{MgO}, \mathrm{CaO}$ and $\mathrm{ZnO}$ NPs are unique due to their high surface areas and unusual crystal structures (Klabunde et al., 1996).

Many farmers of verbascum plants complained of its diseases and lack of production. Therefore, this work aimed to solve their complains.

This study was carried out in Beni-Suef governorate to investigate the causal fungal pathogens affecting verbascum and their control.

\section{Materials and Methods}

\section{1- Survey of verbascum root rot and wilt diseases:}

Survey of verbascum plants aging 2 and 4 months old with typical symptoms of root rot and/or wilt was carried out through two successive growing seasons, (2015/2016 and 2016/2017) at three different counties within 3 different districts in each county belong to Beni-Suef governorate. These counties were Beba, Somosta and Ehnasea. The external symptoms appeared on plants were withering on one branch or more, yellowing, stunting, wilting and /or basal stem rot. Randomly 3 fields from each county cultivated with verbascum plants were chosen to determine the percentage of infection by root rot and /or wilt.

Sampling sites were determined with a field map; five sampling sites were designated per field tested, and one of each of the four directions plus one in the center of the field. Sampling sites were located at least 5 meters from the edge of the field. At least 100 planted holes were examined per each sampling site. The data were expressed as disease incidence (the frequency of infected plants) for each sampling site, from which the field average of infection in the field was calculated.

Egypt. J. Phytopathol., Vol. 46, No. 2 (2018) 
II-Isolation, purification and identification of the associated fungi:

Verbascum plants infected by root rot and /or wilt as well as damping- of seedlings were collected from the nurseries (sandy soil) located in Beni-Suef governorate during 2015/2016 and 2016/2017 seasons. Infected roots and basal stems of seedlings and plants were cut into small pieces, washed thoroughly under running tap water, then surface sterilized using 3\% sodium hypochlorite solution for $3 \mathrm{~min}$, rinsed several times in sterilized distilled water and dried between sterilized filter papers. The pieces were transferred to place on potato dextrose agar (PDA) medium in Petri dishes $(9 \mathrm{~cm}$ in diam), and incubated at $27 \mathrm{C}^{\circ}$ for 7 days with daily observation.

The growing fungal colonies were microscopically examined, counted and the frequency of each fungus was calculated. Purification of the isolated fungi was carried out using the single spore or hyphal tip techniques suggested by Dhingra and Sinclair (1995). These fungi were identified according to Barnett and Hunter (1960), Booth (1977) and Domsch et al. (1980). The identification was kindly confirmed by Mycology and Plant Diseases Survey Dept., Plant Pathol. Res. Inst., Agric. Res. Center., Giza, Egypt. Pure cultures grown into PDA slants were kept at low temperature $\left(5 \mathrm{C}^{\circ}\right)$ for further studies. The frequency of isolated fungi was calculated according to the following formula (Ahmed et al., 2017)

$$
\text { Frequency } \% \text { of fungus }=\frac{\text { No of fungal colonies of each isolated fungus }}{\text { Total Number of fungal colonies of all isolated fungi }} \times 100
$$

\section{III-Pathogenicity studies:}

Pathogenicity experiments were carried out using the purified and identified fungi, which were isolated from the diseased verbascum plants under investigation. Experiments were carried out in the greenhouse of Agric. Exp. Sta. Sides, Beni-Suef Governorate. The fungi were separately grown onto PDA medium for 10 days at $27 \mathrm{C}^{\circ}$. Discs, $5 \mathrm{~mm}$ in diameter, taken from the margins of the fungal colonies were used to inoculate sterilized medium in glass bottles $(500 \mathrm{ml})$ containing sorghum $(80 \mathrm{~g})+$ washed coarse sand $(50 \mathrm{~g})$ and distilled water $(80 \mathrm{ml})$. The inoculated bottles were incubated at $27 \mathrm{C}^{\circ}$ for 21 days and were shaken for several minutes daily for the first five days to ensure uniform distribution of the fungus.

Pathogenicity tests were conducted in sterilized pots $(25$-cm-diam.) containing sterilized soil. However, pots were sterilized by immersing in 5\% formalin solution for 15 minutes, left 10 days to dry and filled with $3 \mathrm{~kg}$ formalin-sterilized soil /each (Nile silt: washed sand, $3: 1, \mathrm{v} / \mathrm{v})$. Soil was infested with adding the inocula of each fungus to the soil at the rate of $3 \%(\mathrm{w} / \mathrm{w})$, mixed thoroughly, watered and left for 7 days to ensure establishment of the inocula. Pots containing soil mixed with the same amount of the autoclaved sorghum sand medium without fungal infestation were served as control.

Verbascum seeds were obtained from the Medicinal \&Aromatic Plants Res. Sta., Hort. Res. Instit., Agric. Res. Center, Beni-Suef governorate. Four pots were sown each 
with approximately 100 seeds $(0.036 \mathrm{~g})$ for each treatment, five seedlings (45-days-old) / pot were transplanted for each treatment. However, number of seeds per each weight was counted because of the variation in their weight and viability.

Disease incidence was recorded as percentages of pre-and post-emergence dampingoff and healthy survived plants 30,60 and 90 days after sowing, respectively. Growth parameters of plants i.e., plant height, fresh and dry weights as well as roots length and fresh and dry weights were also recorded 60 days after sowing. However, dry weight of plant was measured after 15 days of air drying in laboratory. Also, foliage growth parameters (plant height) as well as those of roots (length and fresh and dry weights) and fresh flower yield were recorded 150 days after transplanting. Re-isolation was carried out from the artificially diseased plants in each treatment to fulfill Koch's postulations and the developed fungi were confirmed with the original isolates.

The percentages of disease incidence for root rot and wilt were calculated according to the following formula: (Ahmed et al., 2017).

\section{IV-Disease control}

$$
\text { Disease Incidence }(\%)=\frac{\text { Number of infected plants }}{\text { Total No. of plants }} \times 100
$$

\section{A) In vitro:}

\section{Preparation of fungicides stock solutions:}

The inhibitory effect of three systemic fungicides (Table, 1) against the fungal linear growth of the three of highly pathogenic fungi to verbascum plants was carried out using the poisoned food technique. Five different concentrations $(0,50,100,200$, and 400 $\mathrm{ppm}$ ) of each of the tested fungicides were added to PDA medium before solidification, then medium was dispensed in $(9 \mathrm{~cm}$ in diam.) Petri dishes. Disks, $5 \mathrm{~mm}$ in diameter, taken from 7 days old cultures of any of the tested fungi were transferred to the center of PDA plates and incubated at $25{ }^{\circ} \mathrm{C}$. Five replicate plates were used for each treatment. Control plates were unpoisoned PDA medium. Linear growth of each fungus was recorded after 7 days incubation. The percentage of inhibition activity for each fungicide tested was calculated according to the formula suggested by Topps and Wain (1957) as follows:

$$
\% \text { of inhibition }=\frac{\mathrm{A}-\mathrm{B}}{\mathrm{A}} \times 100
$$

\section{Where,}

$\mathrm{A}=$ Colony diameter $(\mathrm{cm})$ of the fungus in unpoisoned medium

$\mathrm{B}=$ Colony diameter $(\mathrm{cm})$ of the fungus in poisoned medium 
Table (1): Fungicides and nanoparticles of $\mathrm{CuO}, \mathrm{ZnO}$ used through lab experiments.

\begin{tabular}{|l|l|c|c|l|}
\hline \multicolumn{1}{|c|}{$\begin{array}{c}\text { Commercial } \\
\text { Names }\end{array}$} & \multicolumn{1}{|c|}{ Composition } & $\begin{array}{c}\text { Used } \\
\text { rate in } \\
\text { orchard }\end{array}$ & $\begin{array}{c}\% \text { Active } \\
\text { ingredient }\end{array}$ & $\begin{array}{l}\text { the Producing } \\
\text { company }\end{array}$ \\
\hline $\begin{array}{l}\text { Fungicides: } \\
\text { 1-Topsin-M70 }\end{array}$ & $\begin{array}{l}\text { 70\% thiophanate-methyl } \\
\text { (1,2-bis (3-methoxy- } \\
\text { carbonyl-2 thiouredio }) \\
\text { benzene) } \\
\text { Difenoconazole }\end{array}$ & $3 \mathrm{~g} / \mathrm{L}$ & $70 \% \mathrm{WP}$ & $\begin{array}{l}\text { Cerexagri- } \\
\text { Nisso LLC, } \\
\text { Japan }\end{array}$ \\
2-Score & $\begin{array}{l}\text { Mancozeb 40\%+ } \\
\text { Carbendazeam 20\% }\end{array}$ & $3 \mathrm{ml} / \mathrm{L} / \mathrm{L}$ & $250 \mathrm{EC}$ & $\begin{array}{l}50 \% \mathrm{WP} \\
\text { Syngenta, } \\
\text { USA. } \\
\text { 3est Agro } \\
\text { Group, Egypt }\end{array}$ \\
\hline $\begin{array}{l}\text { Nanoparticles: } \\
\text { 1-ZnO-NPs }\end{array}$ & Zno-NPs & $8 \mathrm{mg} \mathrm{L}{ }^{-1}$ & $\begin{array}{l}100 \% \\
\text { Zno-NPs } \\
100 \%\end{array}$ & $\begin{array}{l}\begin{array}{l}\text { Faculty of } \\
\text { Graduate } \\
\text { Studies and } \\
\text { Cuo-NPs } \\
\text { 2-Cuanced }\end{array} \\
\text { 2-Cience, } \\
\text { Bani-Suef- } \\
\text { Egypt }\end{array}$ \\
\hline
\end{tabular}

Preparation of $\mathrm{ZnO}$ and $\mathrm{CuO}$ nanoparticle conc. $\left(\mathrm{mg} \mathrm{L}^{-1}\right)$.

Zinc oxide nanoparticles (ZnO-NP), suspension with size of $70 \pm 15 \mathrm{~nm}$ were obtained from the Faculty of Graduate Studies and Advanced Science (Nanotechnology Department) at Beni-Suef University. According to Sawai and Yoshikawa (2004), an aliquot of ZnO-NPs suspension was vacuumed filtered through an aluminium oxide membrane filter with a $20 \mathrm{~nm}$ pore size and $25 \mathrm{~mm}$ outer diameter (OD), (Anodisc; Whatman Inc., Clifton, NJ, USA), resulting in a NP-free solution. The composition of the NPs-free solution was analyzed, and its effect on fungal growth was examined. The original $\mathrm{ZnO}$ NPs suspension $\left(12 \mathrm{mg} \mathrm{L}^{-1}\right)$ and NPs-free solution were then diluted with melted potato dextrose agar (PDA) to obtain a series of $\mathrm{ZnO}-\mathrm{NPs}$ with concentrations of $0,2,4,6,8$ and $12 \mathrm{mg} \mathrm{L}^{-1}$, respectively and NPs-free solution.

For the synthesis of copper oxide nanoparticles, heated $1.0 \mathrm{mM} \mathrm{CuSO} 4$ solution was added to the heated plant extract flowers of Cassia alatat at 1:1 ratio and stirrer with glass rod for $10 \mathrm{~min}$ and heated in heating mantle for $45 \mathrm{~min}$ at $80^{\circ} \mathrm{c}$. CuO nanoparticles synthesis is indicated by turning of light brown colour to pale green. The change in the color of the reactants indicates the formation of copper oxide nanoparticle. The content was washed in double distilled water thrice by repeated centrifugation at $5000 \mathrm{rpm} 15$ min and the sediments were collected and stored for further characterization after drying 
in an over at $110{ }^{\circ} \mathrm{C}$ over-night. Oven-dried particles were characterized throughout Energy dispersive x-ray spectroscopy (EDS), Scanning electron microscopy (SEM), and $\mathrm{X}$-ray diffraction (XRD) to get details on particles/crystals according to Aruldhas et al. (1998).

\section{B-In Greenhous:}

Four pots were sown each with approximately 100 seeds $(0.036 \mathrm{~g})$ for each treatment, five seedlings (45-days-old)/pot were transplanted for each treatment. Copper, $\mathrm{CuO}, \mathrm{ZnO}$ NPs, fungicides, Tango, Score and Topsin M $70 \% \mathrm{WP}\left(8 \mathrm{mg} \mathrm{L}^{-1}\right.$ and $3 \mathrm{gm} / \mathrm{kg}$ seeds NPs and fungicides, respectively) were used. Soil infestation was carried out similar to the methods described under Pathogenicity test. However, the three pathogenic fungi namely: F. oxysporum Schlecht, Rhizoctonia solani Kühn and. F. solani (Mart.) Sacc were separately used. Verbascum seeds $(0.075 \mathrm{gm}$.) were used to cultivate four pots, thereafter, five seedlings (45-days-old) / pot were transplanted for each treatment. Verbascum transplants were dipped for 15 minutes in each of the $\mathrm{CuO}, \mathrm{ZnO}$ NPs and fungicides .

On the other hand, each of the fungicides used as seed dressing was thoroughly mixed with seeds in plastic bags with small amount of Arabic gum solution (5\%) and were shaken for 10 minutes to obtain uniform distribution.

As regards disease assessments, percentages of pre- and post- emergence dampingoff as well as root rot and wilt plant survival (\%) were determined after 30, 60 and 90 days from planting, respectively. Growth parameters of verbascum plants grown in each treatment included plant height $(\mathrm{cm})$, plant fresh and dry weight were also recorded after 90 days of transplanting in each treatment.

\section{C-In vivo:}

Field experiments were carried out at Agric. Exp. Sta. Sides, Beni-Suef Governorate during two successive seasons, 2015/2016 and 2016/2017 using the complete randomized block design trial. Verbascum seedlings 45 -days-old $(25 \mathrm{~cm} / \mathrm{long})$, obtained from the Medicinal \&Aromatic Plants Res. Sta., Hort. Res. Inst., Agric. Res. Center, Beni-Suef governorate, were planted in the chosen field which was planted with verbascum several times before. Four replicate plots per each treatment were sown with seedlings in September. Each plot $\left(4 \times 5 \mathrm{~m} ; 20 \mathrm{~m}^{2}\right)$ with 7 rows was transplanted with 112 seedlings, 16 ones per each row and $30 \mathrm{~cm}$ as a distance between them. Fungicides and nanoproducts were used as dipping treatment as mentioned under disease control in greenhouse experiments.

The seedlings were directly transplanted after irrigation and in the presence of irrigation water. The plants were irrigated every two weeks and all other agricultural practices were performed as usual whenever necessary. 
Percentages of infected plants showing root rot and /or wilt disease symptoms were recorded, five months from planting. Also, fresh weights per plant ( $\mathrm{g}$ ) as well as dry weight of flower yield $(\mathrm{g})$ were measured at harvest time.

Statistical analysis

Data were statistically analyzed using analysis of variances, and were compared according to the LSD test (Gomez and Gomez, 1984).

\section{Results}

\section{1- The verbascum root rot/wilt distribution in different counties of Beni-Suef}

governorate.

Percentages of natural infection of verbascum seedlings and plants showing disease syndromes, i.e., withering, leaves discoloration or yellowing, stunting, wilting, rotted roots and basal stem rot under field conditions (Figs. 1 and 2) during 2015/2016 and 2016/2017 seasons are shown in Table (2). Root rot and /or wilt diseases were found in all plantations examined in all counties of Beni-Suef governorate. Infection percentages were increased in both surveyed seasons by the increasing in plant age. The highest mean percentages of infection for survey season and plant ages tested was recorded in Ehnasea county, as it was $37.4 \%$ in 2015/2016 and $39.1 \%$ in seasons 2016/2017, respectively. In contrast, the lowest mean of infection percentage was recorded from plants grown in Somosta county, being, $16.1 \%$ and $19.7 \%$ during seasons 2015/2016 and 2016/2017, respectively. The medium percentages of infection were recorded from plants grown in Beba county, being $25.2 \%$ and $31.4 \%$ during 2015/2016 and 2016/2017.

\section{2-Isolation, purification and identification of the associated fungi:}

Isolation trials were carried out from naturally infected verbascum seedlings and plants showing typical symptoms of damping-off, root rot and/or wilt collected from different localities in Beni-Suef governorate, yielded seven different fungal species. These fungal species were identified according to their morphological characters (Table, 3 ). The highest number of fungal colonies (35 colonies) recorded from damped off verbascum seedlings was due to $F$. solani with frequency reached $30.7 \%$ (Table,3). Meanwhile, the highest number of fungal colonies yielded from rotted roots and or wilted verbascum plants was due to $R$. solani. F. solani $(30.70 \%)$ and $R$. solani (21.93 $\%)$ were the most frequently fungi isolated from seedlings showing damping-off and root rot symptoms. Whereas, Helminthosporium sp, Alternaria alternata recorded the lowest percentages of frequency being, 6.14 and 4.38, respectively.

\section{0 - Pathogenicity test:}

Data in Table (4) indicate that all fungi tested, were pathogenic to verbascum seedlings as they significantly increased percentages of pre-and post- emergence damping-off compared with the control treatment. However, the highest percentages of pre and post-emergence damping off were due to infection by $F$. solani and $R$. solani. 
The corresponding values were 21.11 and $51.11 \%$ for $F$. solani and 20.6 and $42.22 \%$ for $R$. solani. In contrast $F$. oxysporum caused the lowest percentages of pre and post emergence damping-off and high rate of survived plants reached 5.55 and $10 \%$.

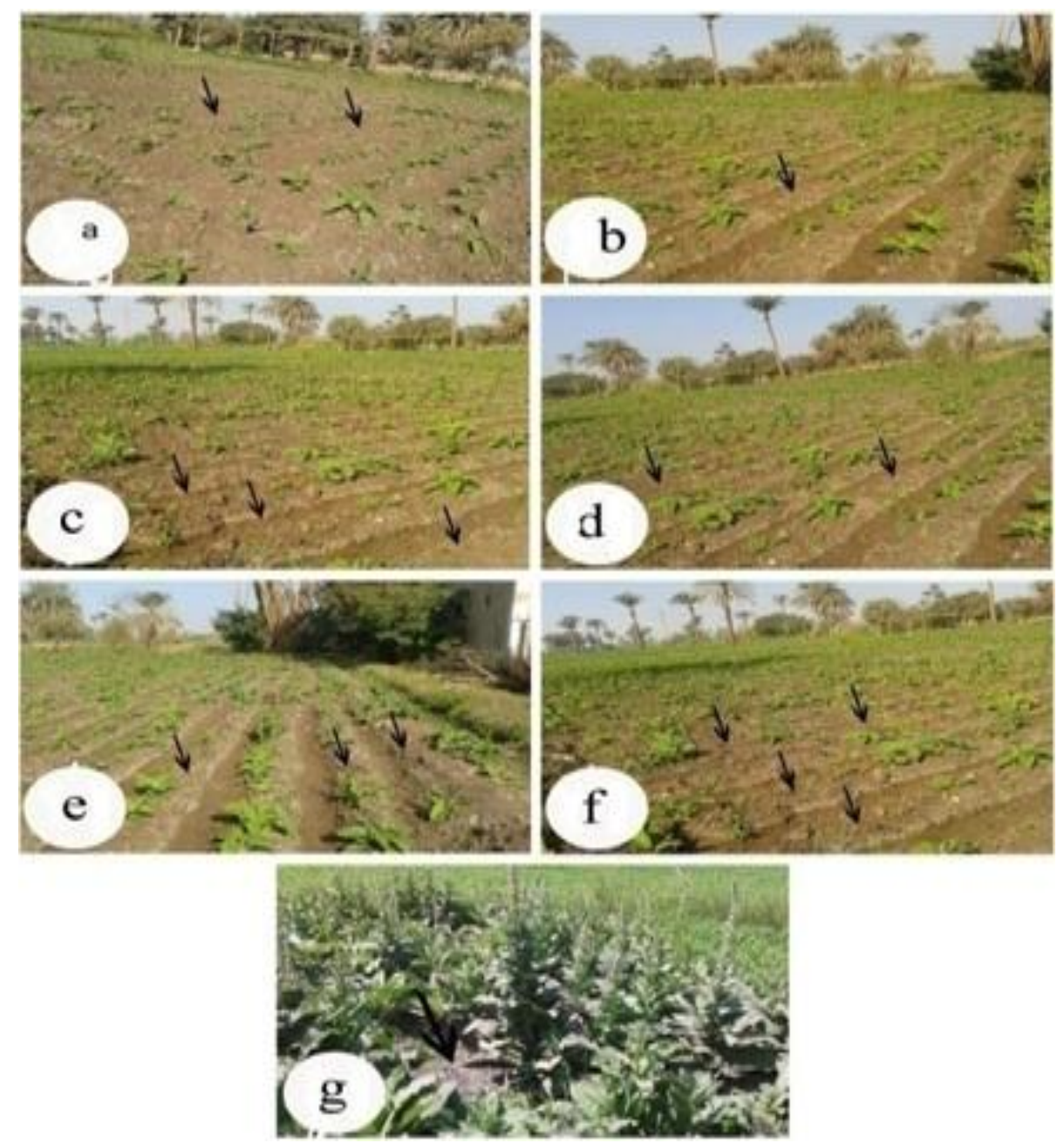

Fig. (1): Natural infection by Soilborne fungi causing pre- and post- emergence damping-off on verbascum plants from Beba county (a and b), Ehnasea county (c and d), Somosta county (e and f) and healthy plants (g). 

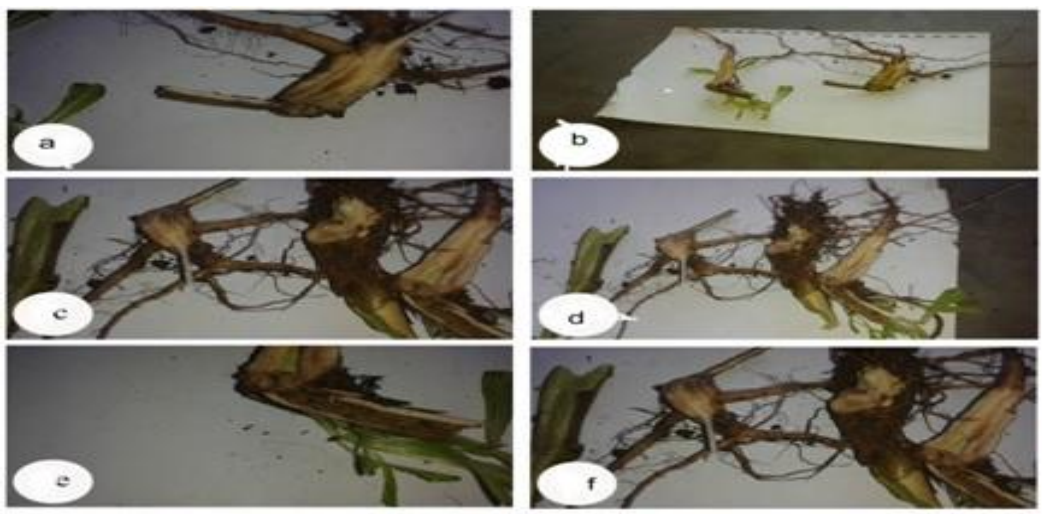

Fig. (2): Longitudinal segments in roots of verbascum plants showing root rot and wilt from Beba county (a and b), Ehnasea county (c and d) and Somosta county (e and f).

Table (2): Percentages of natural infection of verbascum by root-rot and wilt diseases at different counties of Beni-Suef during 2015/2016 and 2016 / 2017 growing seasons.

\begin{tabular}{|c|c|c|c|c|c|c|c|c|c|c|}
\hline \multirow{3}{*}{$\begin{array}{l}\text { Counties and } \\
\text { districts }\end{array}$} & \multicolumn{5}{|c|}{2015 / 2016 season } & \multicolumn{5}{|c|}{$2016 / 2017$ season } \\
\hline & \multicolumn{2}{|c|}{$\begin{array}{l}\text { 2-month- } \\
\text { old* }\end{array}$} & \multicolumn{2}{|c|}{$\begin{array}{l}\text { 4-month- } \\
\text { old }\end{array}$} & \multirow{2}{*}{$\begin{array}{c}\text { over } \\
\text { all } \\
\text { mean }\end{array}$} & \multicolumn{2}{|c|}{$\begin{array}{l}\text { 2-month- } \\
\text { old* }\end{array}$} & \multicolumn{2}{|c|}{$\begin{array}{l}\text { 4-month- } \\
\text { old }\end{array}$} & \multirow{2}{*}{$\begin{array}{c}\text { over } \\
\text { all } \\
\text { mean }\end{array}$} \\
\hline & $\begin{array}{l}\text { Root } \\
\text { rot }\end{array}$ & wilt & $\begin{array}{c}\text { Root } \\
\text { rot }\end{array}$ & wilt & & $\begin{array}{c}\text { Root } \\
\text { rot }\end{array}$ & wilt & $\begin{array}{c}\text { Root } \\
\text { rot }\end{array}$ & wilt & \\
\hline Beba: & & & & & & & & & & \\
\hline 1-Aly kelany & 15.5 & 5.0 & 22.0 & 6.6 & 24.5 & 19.4 & 6.0 & 25.2 & 9.0 & 29.8 \\
\hline 2-El-masharka & 20.0 & 3.4 & 25.6 & 5.0 & 27.0 & 20.9 & 5.0 & 27.5 & 6.0 & 29.7 \\
\hline 3-ELzawya & 18.5 & 4.0 & 16.0 & 10.0 & 24.2 & 18.3 & 12.0 & 20.0 & 17.5 & 34.8 \\
\hline Mean & \multicolumn{2}{|c|}{22.1} & \multicolumn{2}{|c|}{28.4} & 25.2 & \multicolumn{2}{|c|}{27.8} & \multicolumn{2}{|c|}{35.0} & 31.4 \\
\hline $\begin{array}{c}\text { Ehnasea: } \\
\text { 1-Kaferaboshehba }\end{array}$ & 26.0 & 8.4 & 28.6 & 9.0 & 36.0 & 30.0 & 10.2 & 31.0 & 11.7 & 41.4 \\
\hline $\begin{array}{l}\text { 2-Mensheatabdel } \\
\text { samed }\end{array}$ & 30.0 & 10.6 & 31.0 & 11.8 & 41.7 & 25.3 & 11.3 & 28.3 & 12.5 & 38.7 \\
\hline 3-Mensheat taher & 30.6 & 3.3 & 31.2 & 4.3 & 34.7 & 29.2 & 7.0 & 30.0 & 8.5 & 37.3 \\
\hline Mean & \multicolumn{2}{|c|}{36.3} & \multicolumn{2}{|c|}{38.6} & 37.4 & \multicolumn{2}{|c|}{37.6} & \multicolumn{2}{|c|}{40.6} & 39.1 \\
\hline $\begin{array}{l}\text { Somosta: } \\
\text { 1-Bany hala }\end{array}$ & 6.6 & 2.3 & 7.0 & 2.5 & 9.2 & 8.5 & 2.3 & 10.0 & 5.6 & 13.2 \\
\hline 2-Bedahl & 15.0 & 5.6 & 16.5 & 6.3 & 21.7 & 17.0 & 5.2 & 19.4 & 6.5 & 24.4 \\
\hline $\begin{array}{l}\text { 3-Mensheatabo } \\
\text { meleah }\end{array}$ & 10.0 & 5.8 & 13.2 & 6.3 & 17.6 & 15.9 & 5.0 & 15.3 & 7.0 & 21.6 \\
\hline Mean & \multicolumn{2}{|c|}{15.1} & \multicolumn{2}{|c|}{17.3} & 16.1 & \multicolumn{2}{|c|}{18.3} & \multicolumn{2}{|c|}{21.2} & 19.7 \\
\hline
\end{tabular}

$*(\%)$ of plants (2-month-old) exhibited disease symptoms after planting 
Table (3): Fungi isolated from plants showing damping-off and/or root rot symptoms and their frequencies.

\begin{tabular}{|l|c|c|c|c|}
\hline \multirow{2}{*}{ Fungi } & \multicolumn{2}{|c|}{$\begin{array}{c}\text { Damping-off } \\
\text { (45 day old) }\end{array}$} & \multicolumn{2}{c|}{ Root-rot } \\
\cline { 2 - 5 } & $\begin{array}{c}\text { Number of } \\
\text { fungal } \\
\text { colonies }\end{array}$ & $\begin{array}{c}\text { Frequency } \\
(\%)\end{array}$ & $\begin{array}{c}\text { Number of } \\
\text { fungal } \\
\text { colonies }\end{array}$ & $\begin{array}{c}\text { Frequency } \\
\text { ( })\end{array}$ \\
\hline Alternaria alternata & 5 & 4.38 & 9 & 5.45 \\
\hline Fusarium oxysporum & 10 & 8.77 & 15 & 9.09 \\
\hline Fusarium solani & 35 & 30.70 & 45 & 27.27 \\
\hline Helminthosporium sp. & 7 & 6.14 & 10 & 6.06 \\
\hline Macrophomina phaseolina & 13 & 11.40 & 26 & 15.76 \\
\hline Pythium debaryanum & 19 & 16.66 & 25 & 15.15 \\
\hline Rhizoctonia solani & 25 & 21.93 & 35 & 21.21 \\
\hline Total & 114 & 100.00 & 165 & 100.00 \\
\hline
\end{tabular}

Table (4): Percentages of pre- and post- emergence damping-off and survivals of verbascum seedlings after 30, 60 and 90 days, of sowing in infested soil under greenhouse conditions.

\begin{tabular}{|l|c|c|c|}
\hline \multicolumn{1}{|c|}{ Fungi } & $\begin{array}{c}\text { Pre-emergence } \\
(\%)\end{array}$ & $\begin{array}{c}\text { Post-emergence } \\
(\%)\end{array}$ & $\begin{array}{c}\text { Survivals } \\
(\%)\end{array}$ \\
\hline F. oxysporum & 5.0 & 10.00 & 85.00 \\
\hline F. solani & 21.0 & 51.00 & 28.00 \\
\hline M. phaseolina & 8.00 & 12.00 & 80.00 \\
\hline Pythium sp & 14.00 & 25.00 & 61.00 \\
\hline R. solani & 20.00 & 42.00 & 38.00 \\
\hline Control (uninfested soil) & 0.0 & 0.0 & 100 \\
\hline L.S.D. at 5\% & 3.0 & 7.0 & 9.0 \\
\hline
\end{tabular}

Regarding to the effect of tested fungi on the growth parameters of verbascum plants (60 days after transplanting), data presented in Table (5) reveal that all tested fungi significantly minimized verbascum plants height $(\mathrm{cm})$, fresh and dry weights $(\mathrm{g})$ compared with those of control treatment. The lowest growth parameters determined were induced by infection by $F$.solani, being $18.8,16.5$ and $2.8 / \mathrm{g}$ for plant height, plant fresh weight and plant dry weight, respectively. Meanwhile infection by $R$. solani occupied the second rank in this respect. The corresponding values were $22.9 \mathrm{~cm}$ for plant height, $21.6 \mathrm{~g}$ for plant fresh weight and $4.0 \mathrm{~g}$ for dry weight. In contrast, infection by $M$. phaseolina was the least effective treatment in this respect. 
Table (5): Effect of the tested pathogenic fungi on the growth parameters, i.e., plant height $(\mathrm{cm})$, plant fresh weight $(\mathrm{g})$ and plant dry weight $(\mathrm{g})$ of verbascum plants, 60 days after sowing in infested soil, under greenhouse conditions.

\begin{tabular}{|l|c|c|c|}
\hline \multicolumn{1}{|c|}{ Fungi } & $\begin{array}{c}\text { Plant height } \\
(\mathrm{cm})\end{array}$ & $\begin{array}{c}\text { Fresh weight/ } \\
\text { plant }(\mathrm{g})\end{array}$ & $\begin{array}{c}\text { Dry weight } \\
\text { /plant }(\mathrm{g})\end{array}$ \\
\hline F. oxysporum & 30.5 & 36.6 & 6.4 \\
\hline F. solani & 18.8 & 16.5 & 2.8 \\
\hline M. phaseolina & 44.2 & 47.3 & 8.9 \\
\hline Pythium sp. & 32.0 & 29.3 & 5.3 \\
\hline R. solani & 22.9 & 21.6 & 4.0 \\
\hline Control (uninfested soil) & 49.4 & 53.0 & 10.9 \\
\hline L.S.D.at 5\% & 5.0 & 7.0 & 1.0 \\
\hline
\end{tabular}

Data (Table 6) demonstrate that all tested fungi significantly decreased verbascum plant root length $(\mathrm{cm})$ as well as their fresh and dry weights $(\mathrm{g})$ compared with those of control treatment .In this respect, $F$. solani caused the highest reduction in growth parameters followed by $R$. solani. Meanwhile, the lowest effect on these plant growth parameters was due to infection by $M$. phaseolina.

Table (6): Effect of the pathogenic fungi on verbascum growth Parameters, i.e. root length $(\mathrm{cm})$, root fresh weight $(\mathrm{g})$ and dry weight $(\mathrm{g})$ of verbascum plants, 60 days after sowing in infested soil, under greenhouse conditions.

\begin{tabular}{|l|c|c|c|}
\hline \multicolumn{1}{|c|}{ Fungi } & $\begin{array}{c}\text { Root length } \\
(\mathrm{cm})\end{array}$ & $\begin{array}{c}\text { Fresh weight / } \\
\text { Root }(\mathrm{g})\end{array}$ & $\begin{array}{c}\text { Dry weight / } \\
\text { Root }(\mathrm{g})\end{array}$ \\
\hline F. oxysporum & 13.1 & 15.4 & 7.7 \\
\hline F. solani & 10.2 & 11.9 & 6.0 \\
\hline M. phaseolina & 15.2 & 15.5 & 7.8 \\
\hline Pythium sp & 12.0 & 14.1 & 7.4 \\
\hline R. solani & 11.2 & 13.4 & 6.2 \\
\hline Control (without fungus) & 17.0 & 17.3 & 8.7 \\
\hline L.S.D.at 5\% & 1.33 & 1.23 & 0.95 \\
\hline
\end{tabular}

As to the growth parameters of verbascum plants recorded after 150 days of transplanting in soil artificially infested by any of the tested fungi, data in Table (7) reveal that infection by these fungi significantly reduced growth parameters including verbascum plant fresh and dry weight and flowers fresh and dry weights. The highest reduction in these growth parameters was recorded from plants grown in artificially infested soil with $F$. oxysporum followed by $R$. solani, Pythium sp., $F$. solani and $F$. solani and M. phaseolina, respectively. 
Table (7): Effect of the tested pathogenic fungi on growth parameters of verbascum, 60 days after transplanting in infested soil, under greenhouse conditions.

\begin{tabular}{|l|c|c|c|c|}
\hline \multicolumn{1}{|c|}{ Fungi } & $\begin{array}{c}\text { Fresh weight } \\
\text { / plant }(\mathrm{g})\end{array}$ & $\begin{array}{c}\text { Dry weight } \\
\text { / plant (g) }\end{array}$ & $\begin{array}{c}\text { Fresh flower } \\
\text { yield / plant } \\
\text { (g) }\end{array}$ & $\begin{array}{c}\text { Plant height } \\
\text { / plant (cm) }\end{array}$ \\
\hline F. oxysporum & 50.7 & 27.7 & 8.0 & 14.0 \\
\hline F. solani & 151.2 & 77.5 & 11.5 & 33.0 \\
\hline M. phaseolina & 157.5 & 82.2 & 12.5 & 35.0 \\
\hline Pythium sp & 147.5 & 79.2 & 11.0 & 25.0 \\
\hline R. solani & 66.2 & 36.2 & 9.5 & 17.0 \\
\hline Control (without fungus) & 249.5 & 132.2 & 21.7 & 61.0 \\
\hline L.S.D. at 5\% & 12.03 & 7.76 & 2.17 & 11.0 \\
\hline
\end{tabular}

\section{Disease Control}

\section{A: In vitro.}

1-Effect of $\mathrm{ZnO}$ nanoparticle conc. ( $m g \mathrm{~L}-1)$ and $\mathrm{CuO}$ nanoparticle conc. ( $\left.m g \mathrm{~L}^{-1}\right)$ on fungal growth $(\mathrm{cm})$ of three pathogenic fungi to verbascum.

Data presented in Table (8) show that each of ZnO-NPs conc. $\left(\mathrm{mg} \mathrm{L}^{-1}\right)$ and CuO-NPs significantly inhibited the mycelial growth of verbascum pathogenic fungi at different concentrations tested as compared to the control treatment. The inhibition activity of $\mathrm{CuO}-\mathrm{NPs}$ and $\mathrm{ZnO}-\mathrm{NPs}$ was significantly increased with increasing of their concentrations. $\mathrm{CuO}-\mathrm{NPs}$ and $\mathrm{ZnO}-\mathrm{NPs}$ at $6 \mathrm{mg} / \mathrm{l}$ completely inhibited growth of $F$. oxysporum and $R$. solani and caused also great reduction in the mycelial growth of $F$. solani. Using of $8 \mathrm{mg} / \mathrm{l}$ of any of the tested nanoparticles resulted in complete inhibition for the growth of any tested fungi.

Table (8): Effect of $\mathrm{ZnO}$ nanoparticle conc. $\left(\mathrm{mg} \mathrm{L}^{-1}\right)$ and $\mathrm{CuO}$ nanoparticle conc. $\left(\mathrm{mg} \mathrm{L}^{-1}\right)$ on linear growth $(\mathrm{cm})$ of three pathogenic fungi to verbascum.

\begin{tabular}{|c|c|c|c|c|c|c|c|c|c|c|c|c|}
\hline \multirow[b]{2}{*}{$\begin{array}{l}\text { Con } \\
\mathrm{mg} \\
\mathrm{L}^{-1}\end{array}$} & \multicolumn{6}{|c|}{ Zno nanoparticle conc. $\left(\mathrm{mg} \mathrm{L}^{-1}\right)$} & \multicolumn{6}{|c|}{ Cuo nanoparticle conc. $\left(\mathrm{mg} \mathrm{L}^{-1}\right)$} \\
\hline & 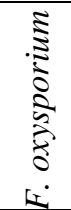 & 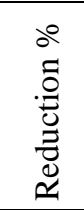 & 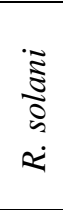 & 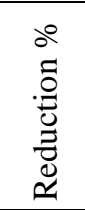 & $\begin{array}{c}\frac{\tilde{\Xi}}{0} \\
\vdots \\
\vdots \\
1\end{array}$ & 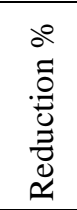 & 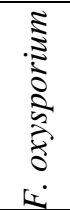 & 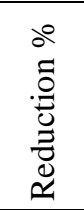 & 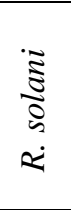 & 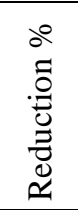 & $\frac{\tilde{\Xi}}{0}$ & 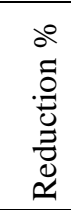 \\
\hline 0 & 9.0 & 0.0 & 9.0 & 0.0 & 9.0 & 0.0 & 9.0 & 0.0 & 9.0 & 0.0 & 9.0 & 0.0 \\
\hline 2 & 3.0 & 66.6 & 4.0 & 55.5 & 4.8 & 46.6 & 4.5 & 50 & 4.7 & 47.7 & 7.5 & 16.6 \\
\hline 4 & 1.7 & 81.1 & 2.2 & 75.5 & 2.3 & 74.4 & 2.8 & 68.8 & 3.7 & 58.8 & 5.1 & 43.3 \\
\hline 6 & 0.4 & 95.5 & 0.0 & 100 & 0.0 & 100 & 0.0 & 100 & 0.0 & 100 & 0.0 & 100 \\
\hline 8 & 0.0 & 100 & 0.0 & 100 & 0.0 & 100 & 0.0 & 100 & 0.0 & 100 & 0.0 & 100 \\
\hline
\end{tabular}

Egypt. J. Phytopathol., Vol. 46, No. 2 (2018) 
2- Effect of fungicides on fungal growth ( $\mathrm{cm}$ ) of three pathogenic fungi to verbascum.

Data presented in Table (9) show that fungicides tested significantly inhibited the mycelial growth of the pathogenic fungi of verbascum at different degrees as compared with the control treatment. The inhibitory effect of the fungicides was significantly increased with increasing their concentrations. Tango was significantly the most active fungicide against mycelial growth of $F$. oxysporum and $R$. solani, since it completely inhibited the mycelial growth $(100 \%)$, at $200 \mathrm{ppm}$ concentration. On contrast, Score fungicide ranked the least as active means against mycelia growth of the tested fungi in this respect.

Table (9): Effect of some fungicides on the linear growth of three verbascum pathogenic fungi in vitro.

\begin{tabular}{|c|c|c|c|c|c|c|c|c|c|c|c|c|c|c|c|c|c|c|}
\hline \multirow[b]{3}{*}{$\begin{array}{l}\dot{\Xi} \\
\tilde{a} \\
\dot{0} \\
\tilde{\Xi} \\
\tilde{\Xi}\end{array}$} & \multicolumn{18}{|c|}{ Effect of fungicides on } \\
\hline & \multicolumn{6}{|c|}{ Tango } & \multicolumn{6}{|c|}{ Score } & \multicolumn{6}{|c|}{ Topsin } \\
\hline & 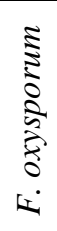 & 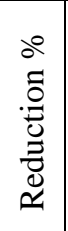 & $\begin{array}{l}\tilde{\Xi} \\
\frac{\tilde{z}}{0} \\
\vdots \\
\dot{\varepsilon}\end{array}$ & 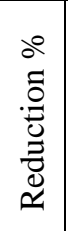 & 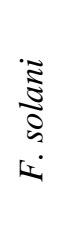 & 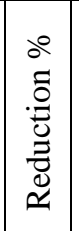 & 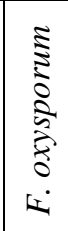 & 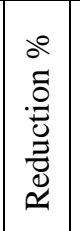 & $\begin{array}{l}\overrightarrow{3} \\
\frac{\tilde{3}}{0} \\
\vdots \\
\vdots \\
\dot{2}\end{array}$ & 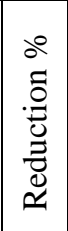 & $\begin{array}{l}\tilde{\Xi} \\
\frac{\tilde{0}}{0} \\
\vdots \\
0\end{array}$ & 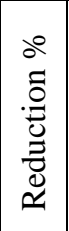 & $\begin{array}{c}\vdots \\
\vdots \\
\vdots \\
\vdots \\
\vdots \\
\vdots \\
\vdots \\
0 \\
0\end{array}$ & 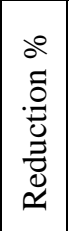 & $\begin{array}{l}\stackrel{\tilde{\Xi}}{\tilde{O}} \\
\tilde{0} \\
\dot{2}\end{array}$ & 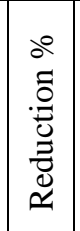 & 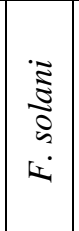 & 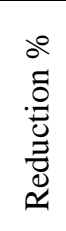 \\
\hline 0.0 & 9.0 & 0.0 & 9.0 & 0.0 & 9.0 & 0.0 & 9.0 & 0.0 & 9.0 & 0.0 & 9.0 & 0.0 & 0.0 & 9.0 & 0.0 & 9.0 & 0.0 & 0.0 \\
\hline 50 & 4.0 & 55 & 5.0 & 44 & 4.5 & 50 & 6.5 & 27 & 5.5 & 38 & 6.3 & 30 & 6.5 & 27 & 6.8 & 24.4 & 6.7 & 25.5 \\
\hline 100 & 3.0 & 66 & 4.0 & 55 & 3.2 & 64 & 4.6 & 48 & 4.5 & 50 & 4.8 & 46 & 5.7 & 36 & 5.5 & 38.8 & 5.4 & 40.0 \\
\hline 200 & 1.5 & 83 & 0.0 & 100 & 2.4 & 73 & 3.1 & 65 & 2.9 & 67 & 2.4 & 73 & 3.1 & 65 & 3.7 & 58.8 & 2.4 & 73.3 \\
\hline 400 & 0.0 & 100 & 0.0 & 100 & 0.0 & 100 & 0.0 & 100 & 0.0 & 100 & 0.0 & 100 & 100 & 0.0 & 100 & 0.0 & 100 & 100 \\
\hline & & & & & & O & 04 & & & & & & & & & & & \\
\hline
\end{tabular}

\section{B: Under Greenhouse}

\section{1-Effect of different tested means on percentage of damping off:}

Data in Table (10) indicate that all treatments tested significantly decreased the percentages of pre- and post- emergence damping-off of verbascum and increased the healthy survived seedlings compared with the control. CuO-NPS treatment significantly reduced the percentages of both pre-and post-emergence damping off and at the same time increased the percentages of survived plants grown in any infested soil by the tested fungi. 
Table (10): Effect of the tested nanoparticles and fungicides on percentage of damping-off of verbascum.

\begin{tabular}{|c|c|c|c|c|c|c|c|c|c|c|}
\hline \multirow[b]{3}{*}{ Treatments } & \multirow[b]{3}{*}{$\begin{array}{l}\text { Dose } \\
\text { at } \\
\text { the } \\
\text { rate }\end{array}$} & \multicolumn{9}{|c|}{ Effect of treatments on: } \\
\hline & & \multicolumn{3}{|c|}{$\begin{array}{c}\text { Fusarium } \\
\text { oxysporum }\end{array}$} & \multicolumn{3}{|c|}{$\begin{array}{c}\text { Rhizoctonia } \\
\text { solani }\end{array}$} & \multicolumn{3}{|c|}{ Fusarium solani } \\
\hline & & 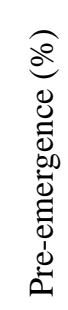 & 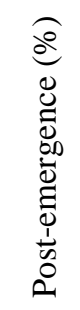 & 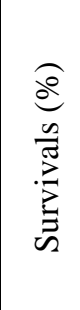 & 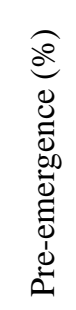 & 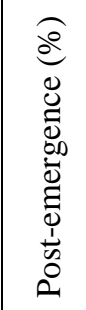 & 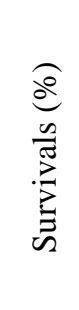 & 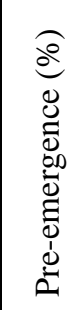 & 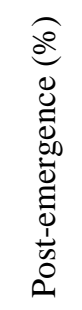 & 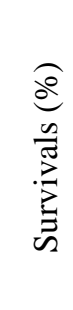 \\
\hline \multicolumn{11}{|l|}{ Nanoparticles : } \\
\hline 1-Cuo-NPs & $8 \mathrm{mg} / \mathrm{l}$ & 2.0 & 1.0 & 97.0 & 2.0 & 3.0 & 95.0 & 3.0 & 5.0 & 92.0 \\
\hline 2-Zno-NPs & $8 \mathrm{mg} / \mathrm{l}$ & 5.0 & 3.0 & 92.0 & 6.0 & 8.0 & 86.0 & 9.0 & 10.0 & 81.0 \\
\hline \multicolumn{11}{|l|}{ Fungicides: } \\
\hline 1-Topsin & $3 \mathrm{~g} / 1$ & 10.0 & 15.0 & 75.0 & 12.0 & 14.0 & 74.0 & 15.0 & 20.0 & 65.0 \\
\hline 2-Score & $3 \mathrm{ml} / \mathrm{l}$ & 12.0 & 16.0 & 72.0 & 14.0 & 16.0 & 70.0 & 18.0 & 25.0 & 57.0 \\
\hline 3-Tango & $3 g / 1$ & 8.0 & 5.0 & 87.0 & 10.0 & 12.0 & 78.0 & 13.0 & 20.0 & 67.0 \\
\hline Control & - & 20 & 62.0 & 18.0 & 30.0 & 60.0 & 10.0 & 35.0 & 40.0 & 25.0 \\
\hline L.S.D.at $5 \%$ & - & 3.0 & 4.75 & 4.0 & 3.80 & 4.60 & 5.12 & 3.42 & 2.08 & 6.44 \\
\hline
\end{tabular}

Regarding to the effect of the tested nanoparticles and fungicides on growth parameters of verbascum plants grown in infested soil 90 days after transplanting, under greenhouse conditions, data (Table, 11) indicate significant increase in growth parameters of verbascum plants treated with these substances more than the control. Nanoparticles were the most active treatment in increasing growth parameters compared to the other tested treatments. Score fungicide was the least effective treatment in this respect. Differences among these treatments and the others were significant in most cases.

Egypt. J. Phytopathol., Vol. 46, No. 2 (2018) 
Table (11): Effect of nanoparticles and chemical fungicides measures on growth parameters of verbascum plants grown in infested soil 90 days after transplanting under greenhouse conditions.

\begin{tabular}{|l|c|c|c|c|c|c|c|c|c|}
\hline \multirow{2}{*}{ Treatments } & \multicolumn{3}{|c|}{ F. oxysporum } & \multicolumn{3}{c|}{ R. solani } & \multicolumn{3}{c|}{ F. solani } \\
\cline { 2 - 10 } & $\begin{array}{c}\text { Plant } \\
\text { height } \\
(\mathrm{cm})\end{array}$ & $\begin{array}{c}\text { Fresh } \\
\text { weight } \\
(\mathrm{g})\end{array}$ & $\begin{array}{c}\text { Dry } \\
\text { weight } \\
(\mathrm{g})\end{array}$ & $\begin{array}{c}\text { Plant } \\
\text { height } \\
(\mathrm{cm})\end{array}$ & $\begin{array}{c}\text { Fresh } \\
\text { weight } \\
(\mathrm{g})\end{array}$ & $\begin{array}{c}\text { Dry } \\
\text { weight } \\
(\mathrm{g})\end{array}$ & $\begin{array}{c}\text { Plant } \\
\text { height } \\
(\mathrm{cm})\end{array}$ & $\begin{array}{c}\text { Fresh } \\
\text { weight } \\
(\mathrm{g})\end{array}$ & $\begin{array}{c}\text { Dry } \\
\text { weight } \\
(\mathrm{g})\end{array}$ \\
\hline Nanoparticles & & & & & & & & & \\
1-Cuo-NPS & 200 & 215 & 170 & 210 & 220 & 125 & 195 & 400 & 203 \\
2-Zno-NPS & 190 & 210 & 155 & 200 & 215 & 103 & 190 & 300 & 155 \\
\hline Fungicides & & & & & & & & & \\
1-Topsin M70 & 175 & 190 & 95 & 180 & 185 & 90 & 185 & 193 & 93 \\
2-Score & 170 & 187 & 85 & 175 & 184 & 85 & 180 & 202 & 95 \\
3-Tango & 180 & 200 & 120 & 185 & 200 & 105 & 186 & 227 & 85 \\
\hline control & 125 & 100 & 45 & 130 & 150 & 50 & 135 & 105 & 54 \\
\hline L.S.D.at 5 \% & 7.03 & 9.75 & 12.50 & 5.76 & 13.29 & 6.50 & 3.75 & 15.73 & 4.66 \\
\hline
\end{tabular}

Field experiment

Data presented in Table (12) demonstrate that all tested treatments significantly decreased the percentages of infection compared with control treatment. The lowest percentages of root rot and wilt $(9 \%)$ and $(8 \%)$ were resulted from transplants treated with copper oxide CuO-NPs in 2015/2016 and 2016/2017 proved to be the superior treatment, since it significantly decreased infection followed by ZnO-NPs $(13 \%)$ and (10 \%) in 2015/2016 and 2016/2017, respectively comparing with the other treatments. On the contrary, transplants treated with Score fungicide showed 52 and $40 \%$ infection by root rot and wilt disease in 2015/2016 and 2016/2017, respectively and this was the least effective treatment followed by Topsin M 70. On the other hand, all treatments significantly increased growth parameters compared with the control treatment. In this regarded, CuO-NPS figured the highest growth parameters per plant with significant difference than the other treatments. However, measurements of growth parameters resulted from applying the $\mathrm{CuO}-\mathrm{NPs}$ were significantly higher than those of the other treatments. Score followed by Topsin were the least effective treatments in this regards.

As for dry weight /plant (g), all treatments recorded significant increases in dry weight /plant $(\mathrm{gm})$ per plant compared with the control. CuO-NPs was, however, the best treatment in this respect. 
Table (12): Effect of various control measures on percentages of infection (root rot and wilt), fresh weight/plant (g) and dry flowers weight/plant (g) of verbascum plants, grown under naturally infested field soil, 2015/2016 and 2016/2017 seasons.

\begin{tabular}{|l|c|c|c|c|c|c|c|}
\hline \multirow{2}{*}{ Treatments } & \multirow{2}{*}{ Rate } & \multicolumn{3}{|c|}{$2015 / 2016$} & \multicolumn{3}{|c|}{$2016 / 2017$} \\
\cline { 3 - 8 } & $\begin{array}{c}\text { Infection } \\
\% *\end{array}$ & $\begin{array}{c}\text { Fresh } \\
\text { weight } \\
(\mathrm{g})\end{array}$ & $\begin{array}{c}\text { Dry } \\
\text { weight } \\
(\mathrm{g})\end{array}$ & $\begin{array}{c}\text { Infection } \\
\%^{*}\end{array}$ & $\begin{array}{c}\text { Fresh } \\
\text { weight } \\
(\mathrm{g})\end{array}$ & $\begin{array}{c}\text { Dry } \\
\text { weight } \\
(\mathrm{g})\end{array}$ \\
\hline Nanoparticles & & & & & & & \\
1-Cuo-NPS & $8 \mathrm{mg} \mathrm{L}^{-1}$ & 9.0 & 1505 & 102.5 & 8.0 & 1510 & 104 \\
2-Zno-NPS & $8 \mathrm{mg} \mathrm{L}^{-1}$ & 13.0 & 1303.7 & 92.5 & 10.0 & 1308 & 100 \\
\hline Fungicides & & & & & & & \\
1-Tango & $3 \mathrm{~g} / 1$ & 17.0 & 1180 & 62.5 & 15.0 & 1200 & 80 \\
2-Topsin & $3 \mathrm{~g} / 1$ & 31.0 & 988.3 & 24.0 & 29.0 & 990 & 90 \\
3-Score & $3 \mathrm{ml} / 1$ & 52.0 & 915.8 & 22.3 & 40.0 & 950 & 110 \\
\hline Control & - & 68.0 & 884.9 & 17.3 & 70.0 & 900 & 40 \\
\hline L.S.D.at 5\% & & 3.54 & 25.68 & 5.73 & 4.55 & 29.77 & 5.99 \\
\hline
\end{tabular}

* Infection with root-rot and wilt diseases

\section{D is c u s sion}

Survey of verbascum root rot and wilt diseases was carried out from verbascum fields located in Beni-Suef governorate. The highest percentages of infection by these diseases were recorded from plants grown in Ehnasea county whereas, the least percentages of infection were recorded from fields located in Somosta county. The symptoms of diseased plants included a drooping and yellowing of the leaves, browning of underground plant parts and eventual death of the plant in infected verbascum fields. Root rot and wilt of verbascum are among the major diseases that are caused by a soil and seed borne vascular wilt pathogen (Garibaldi and Berlti, 2009). Seven fungal isolates were isolated from naturally root rotted and wilted verbascum plants. Fungal isolates were identified as Rhizoctonia solani, Fusarium solani, Fusarium oxysporum, Macrophomina phaseolina, Pythium debaryanum, Alternaria alternata and Helminthosporium sp.

According to the available literature, there have been no studies on diseases of verbascum in Egypt. While, verbascum plants were subjected to some diseases in Italy, (Garibaldi and Berlti, 2009).On the other hand, verbascum is an annual crop and is usually cultivated in the same land for more than three successive years. Therefore, the population of soil borne fungal diseases always increases year after year resulting in a considerable increase in infection percentage on seedlings and / or plants Farr et al. (1989) and Abdel-wahed (2007).

Egypt. J. Phytopathol., Vol. 46, No. 2 (2018) 
Isolation from damped-off seedlings and rotted roots or wilted plants yielded 114 and 165 fungal isolates, respectively represented 6 fungal genera. They, however, were identified to their species as $F$. oxysporum, $F$. solani, $R$, solani, Pythium debaryanum and $M$ phaseolina, $R$. solani and $F$. solani were the most frequently isolated fungi, followed by F. oxysporum. In this respect, Abdel-wahed (2007) in Egypt isolated all these fungi, from chamomile exhibiting the same disease symptoms, Also, one fungus or more of these fungi were isolated from root rot and wilt diseases from each of some medicinal and aromatic plants such as Marigold (Olsen, 1965 \& Lim, 1969), pyrethrum (Ingamells, 1974) and safflower El-Deeb et al., 1983; Farr et al., 1989; Kumar \& Agrawal, 1989 and Majumadar et al., 1989).

Pathogenic potentialities of the tested isolates under greenhouse conditions revealed that all the tested fungal isolates were able to infect verbascum causing damping-off symptoms. The highest percentages of pre and post emergence damping off were recorded from infection by $F$. solani and $R$. solani. $F$. oxysporum caused the least percentages of pre and post emergence damping off. The pathogen was observed to cause typical root rot symptoms including a drooping and yellowing of the leaves, browning of underground plant parts and eventual death of the plant in infected verbascum fields. Root rot and wilt of verbascum are among the major diseases that caused by soil borne fungi (Koike, 2005). These results are similar to those recorded on sweet basil by El-Shazly, (1996) and Garibaldi et al., (1997) and on rue (Helmy et al., 2001).

Results of the in vitro evaluation of nanoparticles and fungicides against the growth of root rot and wilt fungi of verbascum indicated that the tested concentrations of the tested Nanoparticles of $\mathrm{ZnO}$ and $\mathrm{CuO}$ and two Fungicides significantly reduced the linear growth of the tested pathogenic fungi. Tolerance of the tested fungi to the tested doses of nanoparticles and fungicides used was different. Complete growth of inhibition of $F$. solani, F. oxysporum and $R$. solani was achieved by $8 \mathrm{mg} \mathrm{L}^{-1}$ of nanoparticles of any $\mathrm{CuO}$ or $\mathrm{ZuO}$ whereas, fungicides with completely inhibited the growth of the fungi tested at $400 \mathrm{ppm}$.

Zinc, ZnO-NPs are usually present in a form of agglomerates during manufacturing process (Zhang et al., 2007). Two methods, ultrasonication and addition of dispersants, are often used to break down NP agglomerates. Commonly used dispersants include polyvinylpyrolidone, polyethylene glycol, and other chemicals (Brayner et al., 2006). The use of $\mathrm{ZnO}$ NPs suspension efficiently inhibited fungal growth of $F$. oxysporum, $F$. solani and $R$. solani. These results suggest that ZnO NPs may disrupt and damage the conidia of fungi. Consequently, the growth was deeply inhibited. F. solani was more sensitive than $F$. oxysporum to the $\mathrm{ZnO} \mathrm{NPs}$ treatment. Hence, different antifungal effects may result from different growth morphologies of fungi. $F$. solani tends to grow more densely on the surface of the medium than $F$. oxysporum, so it has a larger contact area with $\mathrm{ZnO} \mathrm{NPs}$ than $F$. oxysporum. 
He et al. (2011) found that $\mathrm{ZnO} N \mathrm{NP}$ at concentrations greater than $3 \mathrm{mMol} \mathrm{L}^{-1}$ can significantly inhibit the growth of Botrytis cinerea and $P$. expansum. Sawai and Yoshikawa, (2004) reported that the minimum inhibitory concentration of bulk $\mathrm{ZnO}$ powder against Saccharomyces cerevisiae, Candida albicans, Aspergillus niger, and Rhizopus stolonifer was over $100 \mathrm{mg} \mathrm{ml}-1(\sim 1.2 \mathrm{~mol} \mathrm{~L}-1)$ by an indirect conductimetric assay. ZnO NPs show great enhancement in the antimicrobial activity due to their unique properties such as large surface area.

Brayner et al. (2006); Zhang et al. (2007) and Sharma and Sharma, 2008 proposed that ZnO NPs may cause structural changes of microbial cell membrane, causing cytoplasm leakage and eventually the death of bacterial cells.

Results of the greenhouse revealed that using $8 \mathrm{mg} / \mathrm{L}$ and $3 \mathrm{gm} / \mathrm{L}$ concentrations of the tested nanoparticles and fungicides can controlling root rot and wilt diseases of verbascum. CuO-NPs was the best of the tested treatments to control root rot and wilt on verbascum. All treatments reduced the disease incidence. Modes of actions of the tested fungicides on fungi are different. FRAC (2011) reported that Topsin and Kemazed arrests mitosis and cell division of the tested fungi and affects fungal protein-kinase in osmotic signal transduction. Such results are in agreement with Brayner et al. (2006).

Variation in efficiency of the tested treatment in controlling damping off, root rot and wilt diseases under greenhouse and / or field conditions may be referred to the tested pathogens and mode of action of the tested treatments.

It could be suggested that treating verbascum with nanoparticles and fungicides can be used commercially for controlling damping off, root rot and wilt diseases under a nursery and / or field conditions.

\section{References}

Abdel-wahed,G.A. 2007. Studies on Root Rot and Wilt Fungal Diseases of Chamomile (Matricaria chamomilla) and their control. M.Sc. Thesis, Fac. Agric., Al-Azhar Univ., Cairo, Egypt. 170 pp.

Ahmed, Heba, Z.; Hanaa, Armanious , A.; Maisa, Abdel-Moneim, L. and Galal, A. 2017. Control of root rots and wilt diseases of Marjoram by using some mineral compounds and antioxidants. Minia. J. of Agric. Res. \& Develop., 37(2): 141-156.

Aruldhas, N.; Raj, C. and Gedanken, A. 1998. Synthesis, characterization, and properties of metallic copper nanoparticles Chem. Mater., 10(5): 1446-1452.

Barnett, H.L. and Hunter, B.B. 1960. Illustrated Genera of Imperfect Fungi. McMillan Publ., Comp., N.Y., pp: 280.

Booth, C. 1977. Fusarium laboratory guide to the identification of the major species .Common. Mycol. Inst. Ann. Appl. Biologists, Kew, Surrey, England, pp. 1-58. 
Brayner, R.; Ferrari-Iliou, R.; Brivois, N.; Djediat, S.; Benedetti, M.F. and Fievet, F. 2006. Toxicological impact studies based on Escherichia coli bacteria in ultrafine Zno nanoparticles colloidal medium. Nano. Lett. 6:866-870.

Cioffi, N.; Torsi, L.; Ditaranto, N.; Tantillo, G.; Ghibelli, L. and Sabbatini, L. 2005. Copper nanoparticle polymer composites with antifungal and bacteriostatic properties. Chem. Mater. 17:5255-5262.

Dhingra, O.D.and Sinclair, J.B. 1995. "Basic Plant Pathology Methods". $2^{\text {nd }}$ ed. Lewis Publ., CRC Press, USA, 434 pp.

Domsch, K.H.; Gams, W. and Traute-Heidi, A. 1980. "Compendium of soil Fungi". Academic Press. A subbidiary of Harcourt Brace Jovanvich Publishers, London, pp.859.

Elad, Y.; Yunis, H. and Katan, T. 1992. Multiple fungicide resistance to benzimidazoles, dicarboximides and diethofencarb in field isolates of Botrytis cinerea in Israel. Plant Pathol., 41: 41-46.

El-Deeb, A.A.; El-Wakil, A.A.; Shalaby, H.S. and Hilal, A.A. 1983. Studies on root rot of safflower with special reference to Fusarium semitectum Berk\&Rev. Proc. $8^{\text {th }}$ Inter .Cong. Static. Comp. Sci., Social and Demgraphic Res. (Egypt), pp. 229-238.

El-Shazly, A.M. 1996. Studies on Certain Fungal Diseases on Some Medicinal Plants of Family Labiatae. Ph.D. Thesis, Fac. Agric., Al- Azhar Univ., 188 pp .

Farr,D.F.; Bills, G.F.; Chamuris, G.P. and Rossman, A.M. 1989. Fungi on plants and plant products in the United States. The Amer .Phytopathol . Soc., St. Paul, Minnesota , USA, $1252 \mathrm{pp}$.

FRAC. 2011. Fungicides stored by mode of action. 10 pp (www.frac.org). Garibaldi, A. and Berlti, A. 2009. Diseases of some ornamentals plants investigated in the project Re VFlor. [Italy]. Protezionedelle Colture. (4):3-7. 6.

Garibaldi, A.; Gullino, M.L. and Minuto, G. 1997. Diseases of basil and their management. Plant Dis., 81(2): 124-132.

Garofalo, F. 1970. Wormwood wilt in piedmont and preliminary trials against it .Phytopathol. Mediterranean, 9(2-3): 179-181 (c.f. Rev. Pl. Pathol., 50 (7): 349, 1971).

Gomez, K.A. and Gomez, A.A. 1984. "Statistical Procedures in Agricultural Research", by New York, Chichester, etc.: Willy, $2^{\text {nd }}$ ed., Paperback, PP. 1- 680.

Gu, H.; Ho, P.L.; Tong, E.; Wang, L. and Xu, B. 2003. Presenting vancomycin on nanoparticles to enhance antimicrobial activities. Nano. Lett. 3: 1261-1263. 
Hamed, Nawal, M. and Mohamed, Abeer, E. 2010. Studies of biologically active constituents of Verbascum and its induction resistance against some diseases of cucumber. Drug Plants I., 2010:141-159. 49 ref.

Hanafi, Y.A. and Abdel wahab, M.A. 2013. Production of medicinal, aromatic, floral, and root plants in the new lands. General Directorate of Agricultural Culture. Technical Bulletin. No. 17. 41-42.

He, L.; Liu, Y.; Mustapha, A. andsww Lin, M. 2011. Antifungal activity of zinc oxide nanoparticles against Botrytis cinerea and Penicillium expansum. Microbiol. Res. 166:207-215.

Helmy, A.A.; Baioumy, M.A. and Hilal, A.A. 2001. Frist record of root rot and wilt diseases of the medicinal plant Ruta graveolens L. in Egypt and their control. Egypt. .J. Agric. Res., 79(1): 21-35.

Ingamells, C.J. 1974. Root rot of Pyrethrum in South Africa. Phytophylatica, 6(3): 203204 (c.f. Rev. Pl. Pathol., 54(6): 447,1975).

Kim, K.J.; Sung, W.S.; Moon, S.K.; Choi, J.S.; Kim, J.G. and Lee, D.G. 2008. Antifungal effect of silver nanoparticles on dermatophytes. J. Microbiol. Biotechnol. 18:1482-1484.

Klabunde, K.J.; Stark, J.; Koper, O.; Mohs, C.; Park, D. and Decker, S. 1996. Nanocrystals as stoichiometric reagents with unique surface chemistry. J. Phys. Chem. 100: 12142-12153.

Koike, S.T. 2005. First Report of Fusarium Wilt of Cilantro Caused by Fusarium oxysporum in California. Plant Disease, 89(10) 1,130.1

Kumar, H. and Agrawal, R.K. 1989. HUS 305 a high-yielding safflower variety. Indian Farming, 39(5): 17-18 (CAB Abst. 1990-1991).

Kumar, P.K.; Vemula, P.M.; Ajayan, G. and John, D. 2008. Silver-nanoparticle embedded antimicrobial paints based on vegetable oil. Nat. Mater. 7: 236-241.

Lim, G. 1969. Fusarium wilt of Marigolds. Mycopath. Mycol. Appl., 39(3-4): 345-348 (c.f. Rev. Pl. Pathol., 49:292, 1970).

Liu, Y.; He, L.; Mustapha, A.; Li, H. and Lin, M. 2009. Antibacterial activities of zinc oxide nanoparticles against Escherichia coli O157:H7. J. Appl. Microbiol. 107: 1193-1201.

Majumadar, A.; Shamsher, S.; Bisht, S. and Singh, S. 1989. Safflower: its diseases and their management. Seeds and Farms, 15(2): 3-4 (CAB Abst. 1990-1991). 
Ocamb, C.M.; Hamm, P.B and Johnson, D.A. 2007. Benzimidazole resistance of Fusarium species recovered from potatoes with dry rot from storages located in the Columbia basin of Oregon and Washington. Am. J. Potato. Res. 84: 169-177.

Olsen, C.M. 1965. Fusarium wilt of Tagets Marigolds. Phytopathology, 55(7): 711-714.

Sawai, J. and Yoshikawa, T. 2004. Quantitative evaluation of antifungal activity of metallic oxide powders $(\mathrm{MgO}, \mathrm{CaO}$ and $\mathrm{ZnO})$ by an indirect conductimetric assay. J. Appl. Microbiol. 96: 803-809.

Sharma, N. and Sharma, S. 2008. Control of foliar diseases of mustard by Bacillus from reclaimed soil. Microbiol. Res. 163: 408-413.

Stoimenov, P.K.; Klinger, R.L.; Marchin, G.L. and Klabunde, J.S. 2002. Metal oxide nanoparticles as bactericidal agents. Langmuir 18: 6679-6686.

Topps, J.H. and Wain, R.L. 1957. Investigations on fungicides: III. The fungi toxicity of 3- and 5- alkyl-salicylanilides and parachloroanilides. Ann. Appl. Biol., 45(3): 506511.

Zhang, L.; Jiang, Y.; Ding, Y.; Povey, M. and York, D. 2007. Investigation into the antibacterial behaviour of suspensions of $\mathrm{ZnO}$ nanoparticles ( $\mathrm{ZnO}$ nanofluids). $J$. Nanoparticle Res. 9: 479-489.

(Received 30/07/2018;

in revised form 02/09/2018) 


\section{مكافحة أمراض سقوط البادرات وذبول واعفان الجذور في الفربسكم باستخدام جزيئات النانو المعدنية والفئول والمبيدات الجات الفطرية . الفريكان}

جمعه عرفات عبد الواحد

قسم بحوث أمراض نباتات الزينة والطبية والعطرية ، معهل بحوث أمراض النباتات ، مركز البحوث الزراعية ، الجيزة ، مصر ولئر ،

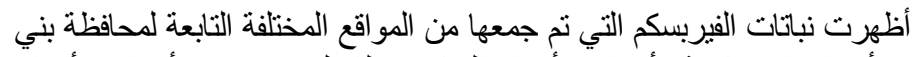

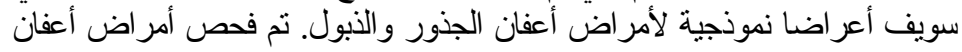

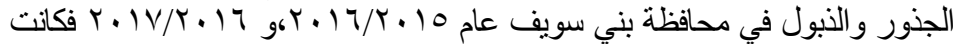

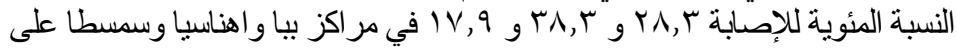

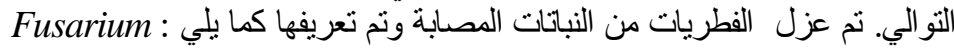
oxysporum, Pythium debaryanum, Alternaria alternata, Rhizoctonia solani, Macrophomina phaseolina, F. solani and R. solani كانت أكثر الفطريات تكرارا الفطر Helminthosporium sp.

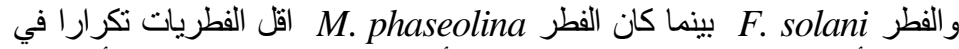

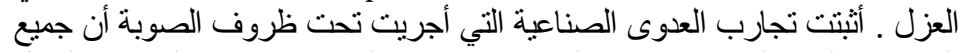

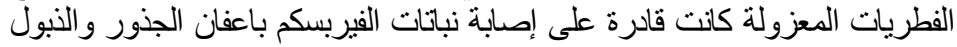

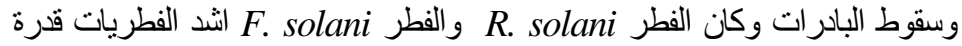

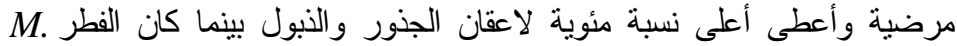
phaseolina

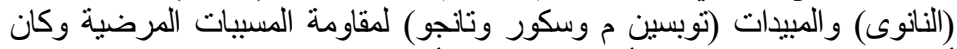

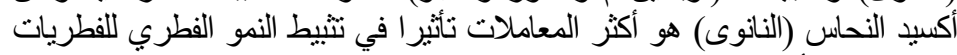

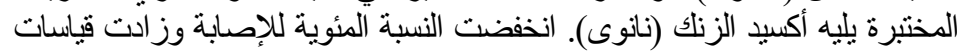
النباتات تحت ظروف الصوبة. أنثتت تجارب الحقل أن كل المعاملات أثرت في حماية

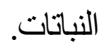

